\title{
LA PUERTA DEL PERDÓN DE LA MEZQUITA-CATEDRAL DE CÓRDOBA
}

\author{
THE FORGIVENESS GATE OF THE \\ MOSQUE-CATHEDRAL OF CÓRDOBA
}

\author{
Mán Ángeles Jordano Barbudo \\ Universidad de Córdoba. España \\ ajordano@uco.es
}

\begin{abstract}
El estudio de la entrada principal a la mezquita-catedral aporta un análisis tipológico como puerta de aparato con el que se concibió bajo Abd al-Rahman III. Su simbolismo en relación con el patio de los Naranjos - jardín del paraíso- y con el resto del edificio ha sido aprovechado por reyes y prelados como medio propagandístico. Enrique II de Trastámara y su hijo Juan I la utilizaron como marco escenográfico para legitimar su poder dotándola de una estética mudéjar, mientras que el obispo Pedro de Tapia encargó el proyecto de un retablo pictórico para exaltar la Asunción de María como titular y propagar la veneración a San Rafael, custodio de la ciudad, mientras que don Pedro Salazar colocó su escudo episcopal en la cúpula barroca.

Palabras clave: ceremonial, Enrique II, obispo, propaganda, puerta de aparato
\end{abstract}

This research about the main entrance to the mosque-cathedral contributes to give a tipological analysis as an entourage gate as it was conceived under Abd al-Rahman III. The kings and prelades have taken advantage of it as a way for their own propaganda thanks to the link between the gate and the Orange courtyard, seen as the paradise garden, and the mosque-cathedral too. Enrique II and his son Juan I made use of the gate as a theatrical setting to legitimize their power under a mudejar appearance, while the bishop Pedro de Tapia comissioned the proyect of a pictorial altarpiece to exalt the title of the Assumption of Mary and propagate the veneration to St. Rafael, the Guardian of Córdoba. Pedro Salazar put his coat of arms in a visible place in the baroque dome.

Keywords: ceremonial, Enrique II, bishop, propaganda, entourage gate

Al ser la entrada principal de la mezquita aljama y seguir siéndolo después de su transformación en iglesia a raíz de la conquista de Córdoba en 1236 por Fernando III el Santo, la puerta del Perdón ha sido objeto de significativas transformaciones en pro de una simbología áulica y en relación con la exaltación del poder episcopal (Figura 1). Salvo unos pequeños vestigios de decoración de época de Abd al-Rahman III, el resto de esta puerta de aparato es resultado 
de intervenciones de época cristiana, siendo la más significativa la de Enrique II. La puerta sirvió como marco escenográfico del soberano y fue utilizada para mostrar la legitimidad de la nueva dinastía Trastámara y aparecer ante sus súbditos como defensor de la fe frente a los infieles.

La reforma de la puerta hay que verla en conexión con la Capilla Real para enterramiento del padre y abuelo de Enrique II, marcando así una política continuista y legitimista a pesar de la bastardía del soberano.

Si la portada había tenido durante la Baja Edad Media un alto contenido político-religioso, a partir de la segunda mitad del s. XVI se convierte en instrumento propagandístico de los obispos. Es el caso de don Pedro de Tapia, en cuya época Antonio del Castillo realiza las pinturas que recuerdan la advocación postrentina de la Asunción para la catedral, al mismo tiempo que evoca el protagonismo de los mártires cordobeses y muestra la devoción y agradecimiento de su feligresía al arcángel San Rafael tras padecer la peste. Don Pedro Salazar y Góngora aportará la cúpula barroca y su escudo pondrá el timbre de gloria.

Desde 1236 las fuentes revelan el uso protocolario de esta entrada y, por tanto, exclusivo en determinadas ceremonias: por ella pasaba el obispo tanto el día de la toma de posesión como el de su entierro; el rey ingresaba por ella cuando estaba en la ciudad; y, por último, el concejo de Córdoba acudía a las ceremonias litúgicas en representación de la ciudad accediendo por este lugar ${ }^{1}$. Las sucesivas intervenciones de que ha sido objeto desde el siglo XIV hasta la actualidad hacen que en las siguientes páginas se lleve a cabo un análisis formal y simbólico de la puerta, cuyo paralelismo con la homónima sevillana es evidente hasta cierto punto.

\section{SIMBOLOGÍA EN ÉPOCA ISLÁMICA Y CRISTIANA. CEREMONIAL}

Constituye un cuerpo arquitectónico dispuesto junto al alminar construido con motivo de la ampliación del patio por Abd al-Rahman III, que fue convertido después en torre cristiana pero con carácter independiente respecto a la puerta de aparato. Esta sobresale en planta y altura respecto al muro que rodea el patio, y se halla constituida por dos arcos de herradura apuntada, separados entre sí por un espacio cubierto con bóveda. Se trata, por tanto, de un ingreso directo, habitual en las ciudades y fortalezas omeyas de al-Andalus, donde iba entre torres -grandes machones en el caso de Córdoba-, de manera que originaban un esquema tripartito de ascendencia romana y bizantina ${ }^{2}$, con amplio eco posteriormente, como es la antigua puerta de Bisagra en Toledo, de Alfonso VI. De esta

${ }^{1}$ NIETO CUMPLIDO, Manuel: La Catedral de Córdoba. Córdoba, 1998, p. 604.

2 PAVÓN MALDONADO, Basilio: Tratado de arquitectura hispanomusulmana: Ciudades y fortalezas. Madrid, 1999, t. 2, pp. 393-395. 
forma, complementaría el aspecto externo de la mezquita como fortaleza de Dios. De hecho, en las fortalezas y castillos se aprovechaba la corraliza o espacio entre las cuatro mochetas para cobijo del centinela ${ }^{3}$.

Esta tipología fue muy frecuente en las fortificaciones, siendo estudiada por Acién Almansa, quien apunta sus orígenes en Samarra. Afirma que siendo 'Abd Allah emir de Córdoba, ordenó construir una puerta de la Justicia donde tenía lugar la audiencia pública, costumbre que se generalizó hasta que progresivamente fue desapareciendo para quedar el nombre y el modelo arquitectónico. El mismo autor sostiene que la puerta monumental de época nazarí conservada en Gibralfaro, junto a la cual se conserva una torre con decoración en yeso en su fachada, que él interpreta como posible árbol del paraíso, se convierte en símbolo del sultán, en su capacidad para pacificar sus reinos y administrar justicia. El modelo también está presente en la puerta de la Justicia de la Alhambra y en Almería ${ }^{4}$. Esta interpretación de Acién es muy interesante. Si la puerta del Perdón de Córdoba se concibió en época califal, bajo Abd al-Rahman III, con esa idea, y de hecho el patio de los Naranjos evoca el paraíso, estaríamos ante un caso de pervivencia conceptual que se prolonga hasta Enrique II y seguirá vigente, al menos, bajo los obispos Tapia (s. XVII) y Salazar y Góngora (s. XVIII).

Efectivamente, en época cristiana su simbolismo fue significativo también. Desde 1364 hay constancia documental del protocolo seguido en la toma de posesión de los obispos:

"Sabado, XX dias de enero era de mill e quatroçientos et dos annos entro en Cordoua el eleyto don Andres et el cabildo con toda la clereçia de la villa et las cruçes et cont todas las ordenes sallieron et lo reçibieron a la puerta del Perdon con capas de seda et el eleyto adoro la cruç et dende leuaronlo en procession fasta el altar mayor et en el altar mayor diole el dean la bendiçion et despues leuaronlo fasta que se asento en su siella et despues desto leuaronlo a su posada [...]"'.

Esta tradición se mantuvo en vigor durante siglos. Gracias al Ceremonial es posible conocer más detalladamente el ritual ${ }^{6}$ : Cuando llegaba un nuevo obispo a

3 PAVÓN MALDONADO, Basilio: Tratado de arquitectura ..., op. cit., pp. 395-396.

${ }^{4}$ ACIÉN ALMANSA, Manuel: "Los tugur del reino de Granada. Ensayo de identificación”. Castrum, 5. Archéologie des espaces méditerranéens au Moyen Âge. Murcia, 1999, p. 433. ACIÉN ALMANSA, Manuel: "La fortificación en Al-Andalus", en La arquitectura del Islam occidental. Barcelona, 1995, pp. 40-41.

5 NIETO CUMPLIDO, Manuel: La Catedral..., op. cit., pp. 604-605; GÓMEZ BRAVO, Juan: Catálogo de los obispos de Córdoba. Córdoba, 1778, t. 1, p. 308.

${ }^{6}$ XIMÉNEZ DEL HOYO, Manuel: Ceremonial y Manual de las preces, himnos, salmos y oraciones que deben decirse en la Santa Iglesia Catedral de Córdoba. Córdoba, 1805, pp. 90-96. Aunque fechado en 1805, el autor del Ceremonial indica en el prólogo que los rituales más solemnes de la catedral se mantuvieron inalterables. Los que se explican en 
la ciudad, el cabildo formaba en la capilla del cardenal Salazar o sacristía, y, una vez concluidas las Completas, marchaban al palacio episcopal, donde eran recibidos por el obispo. Después, todos juntos, con ornamentos blancos, se dirigían en procesión a la catedral, al tiempo que repicaban las campanas, presididos por la cruz alta y acompañados de ciriales, las reliquias y acólitos con sus dalmáticas.

"La dicha puerta principal del Perdón estará cerrada, y en el pórtico se habrá dispuesto un altar debaxo de la cruz que alli hay, con sus blandones y seis luces sobre su mesa, y delante de él un faldistorio para S.I., colocando sobre éste los Estatutos, la fórmula de juramentos y el libro de los Evangelios"'.

Al llegar el obispo, el alcaide abría la puerta y el preste le daba la cruz para que la besara y le hacía entrega del hisopo para que se aspergiera a sí mismo, al preste, ministros, cabildo eclesiástico y municipal. Inmediatamente después, el preste le ofrecía incienso al obispo para que lo bendijese y así aquel pudiera incensar al prelado, "quien arrodillado inmediatamente en el faldistorio hará oración y leerá ante el Secretario capitular el juramento". Concluido este acto, el maestro de ceremonias daba paso al coro para entonar el R. Ecce Sacerdos, dirigiéndose la procesión desde la puerta hasta el altar mayor pasando por los postigos del coro. El paso de la comitiva por el arco de Bendiciones, entrada principal al templo tras cruzar el patio de los Naranjos, era la señal para que las campanas repicaran -a la salida- o dejaran de hacerlo - a la entrada-.

En el caso de fallecimiento del obispo, la procesión de canónigos salía por la puerta de Deanes para cruzar al palacio y recoger el cuerpo: "Tomarán a hombros el cadáver quatro sacerdotes y se dirigirá la procesión a la Santa Iglesia”, precediendo una cruz con manga negra a todas las comunidades ${ }^{9}$.

"Entrará la procesión por la puerta del Perdón y se colocará el cadáver en el túmulo que habrá dispuesto en medio de la crujía: y por esta causa, para principiar el oficio de sepultura, se pondrá la Sta. Cruz a la cabeza del dicho túmulo: y el preste con el Diácono y demás ministros inferiores, a sus pies en la entrada de la dicha crujía, frente al Altar y la Cruz, que deberá haber tomado el Subdiácono. Se principiará la aspersión e incesación en los responsos por el lado de la Epístola: se darán las vueltas correspondientes alrededor del túmulo [.... $]^{\prime \prime 10}$.

Cuando en lugar del obispo se tratara del rey y este "determinare entrar en público en la Iglesia”, se dispondría bajo la pintura de la Asunción de la puerta del

estas páginas están entre los de esa categoría como parece obvio y es muy probable que se respetaran en todo su desarrollo.

7 XIMÉNEZ DEL HOYO, Manuel: Ceremonial y Manual..., op. cit., p. 92.

8 XIMÉNEZ DEL HOYO, Manuel: Ceremonial y Manual..., op. cit., pp. 92-93.

9 XIMÉNEZ DEL HOYO, Manuel: Ceremonial y Manual..., op. cit., p. 532.

10 XIMÉNEZ DEL HOYO, Manuel: Ceremonial y Manual..., op. cit., p. 533. 
Perdón un altar con dosel y, delante de este, un sitial para el rey con almohada rica $^{11}$. El cabildo saldría a recibirle revestido con capas pluviales blancas, presidido por el obispo o el preste precedidos de la cruz procesional y todas las parroquiales. Seis capellanes portarían el palio y el prelado o el preste llevarían la cruz de plata que darían a besar al rey. La comitiva eclesiástica se formaría en la capilla del cardenal Salazar y marcharía hasta la puerta del Perdón para encontrarse con el soberano, quien nada más llegar debía arrodillarse y besar la cruz, mientras el obispo le aspergía. Inmediatamente, los cantores entonarían el R. Elegit y la comitiva comenzaría a bajar hacia el arco de Bendiciones con el rey bajo palio en medio de ella por ser el lugar preeminente, el mismo que ocupaba el pendón real el día de su proclamación.

Este solemne ceremonial se veía acompañado por el repique general de las campanas de la catedral ${ }^{12}$, al tiempo que todos escuchaban las voces entonando salmos de tradición davídica especialmente elegidos para la consagración de los reyes y otras ceremonias reales, en este caso el Elegit, que proclamaba los favores otorgados por Dios al pueblo de Israel desde su peregrinación a Egipto. No obstante, el Ceremonial de 1805 sigue el Pontifical Romano de Clemente VIII surgido después de Trento y vigente prácticamente hasta el concilio Vaticano II. Se ha producido una adaptación del texto original para hacerlo más comprensible al pueblo, pero el mensaje sigue siendo el mismo: una loa a la elección del rey por Dios y una declaración de su prudencia y buen gobierno. Así, en el Salmo original se manifestaba que la tribu de Judá, a la que Dios amaba, había sido escogida por Él (Sed elegit tribum Iuda: montem Sion, quem dilexit) ${ }^{13}$. En este caso, remontándonos a la época de la conquista cristiana, las inscripciones de la portada se veían reforzadas con cánticos convenientemente escogidos para subrayar el triunfo de la cruz y del pueblo elegido. Es más, se hacía notar la elección del rey David por Dios y la promesa divina de perpetuar su dinastía, en este caso representada por el rey castellano (Et elegit David servum suum $)^{14}$ que gobierna a

11 XIMÉNEZ DEL HOYO, Manuel: Ceremonial y Manual..., op. cit., pp. 129 y 133. En caso de que viniese acompañado de la reina, se dispondrá un sitial al lado del rey, y si vinieren más miembros de la realeza, se colocarán "otras tantas almohadas en el pórtico del Perdón".

${ }^{12}$ Durante el recorrido desde el palacio hasta el arco de Bendiciones y también al regreso.

${ }^{13}$ FERNÁNDEZ, Fray Diego: Traducción literal del Salterio de David al idioma castellano, y del cántico de Nuestra Señora, de Simeón, de Zacarías y el de los tres niños. Segovia, 1801, p. 190. <https://books.google.es/books/download/Traducción_literal_del_Salterio_de_Davi.pdf. Consultado el 20/06/2015>.

${ }^{14}$ El salmo que se entonaba en la puerta del Perdón poco variaba en cuanto al mensaje: "Elegit eum Dominus, et excelsum fecit illum prae Regibus terrae" [Lo eligió el Señor y lo dignificó, lo glorificó ante los ojos de los soberanos y no será confundido]. FERNÁNDEZ, Fray Diego: Traducción literal..., op. cit., p. 190. 
su pueblo (Pascere Iacob servum suum: et Israel haereditatem suam ${ }^{15}$ con nobleza y prudencia, culminando así con la imagen del buen gobierno (Et pavit eos in innocentia cordis sui: et in intellectibus manuum suarum deduxit eos $)^{16}$.

El carácter mayestático de la puerta del Perdón hizo que esta quedara reservada a los actos referidos, celebrados muy puntualmente. Su uso solemne, alejado de la popularidad que pudieran tener las procesiones devocionales y litúrgicas, se deja ver en que únicamente el día de los difuntos, tras la misa, se hacía un recorrido por las capillas de la catedral para rezar un responso ante ellas y, en un momento dado, la procesión salía al patio, y, haciendo un recorrido por su perímetro interno, llegaba hasta "el postigo de la torre" para hacer el responso correspondiente ${ }^{17}$.

\section{EL SIMBOLISMO DE LA PUERTA BAJO LOS TRASTÁMARA}

Tras la obra de la nueva puerta que tuvo que acometer Abd al-Rahman III al ampliar el patio, la siguiente empresa importante de la que tenemos constancia es la llevada a cabo por Enrique II, la cual hay que ver en el contexto de un ambicioso programa que afectaba a tres significativos hitos del templo. No solo interviene en los dos accesos principales - puerta del Perdón (1377) y arco de Bendiciones- ${ }^{18}$, sino que erige la Capilla Real (1371). Enrique II, primer rey de la dinastía Trastámara, que se había hecho con el trono tras el asesinato de su hermanastro Pedro I en Montiel, y que contaba con apoyo mayoritario de la nobleza cordobesa, hace patente su legitimidad mediante una intervención prácticamente sin precedentes en la mezquita por parte de sus antecesores ${ }^{19}$. Extremó los cuidados en adecuar al gusto imperante la puerta que habría de servirle de marco escenográfico en la ciudad que le había respaldado frente a las fuerzas petrinas ${ }^{20}$. Elige el mudéjar como fórmula estética, como había hecho el rey Pedro en los Alcázares sevillanos, en sintonía igualmente con lo que se estaba haciendo en otro centro de poder importante en aquel entonces, la Alhambra de Granada. En

15 "Para que pastorease a Jacob su siervo: y a Israel, que es su heredad". FERNÁNDEZ, Fray Diego: Traducción literal..., op. cit., p. 190.

16 "Y él les apacentó con una inocencia propia de su corazón: y les gobernó con las prudentes obras de sus manos”. FERNÁNDEZ, Fray Diego: Traducción literal..., op. cit., p. 190.

${ }^{17}$ FERNÁNDEZ, Fray Diego: Traducción literal..., op. cit., p. 590.

18 JORDANO BARBUDO, Ma Ángeles: El Mudéjar en Córdoba. Córdoba, 2002, pp. 91-92.

19 Únicamente la fundación de la capilla de San Clemente por Alfonso X. En cuanto a Enrique IV, hasta su traslado por su nieto Enrique II a la Capilla Real, estuvo enterrado en la catedral, pero no hay constancia de una intervención arquitectónica por su parte.

20 JORDANO BARBUDO, Ma Ángeles: La Sinagoga de Córdoba y las yeserías mudéjares en la Baja Edad Media. Córdoba, 2011, pp. 164-165. 
definitiva, se trataba de hacer ostensible la legitimación del ascenso del primer Trastámara al trono sirviéndose para ello de la arquitectura y de las formas estéticas que lleva aparejadas. El escudo cuartelado de Castilla y León en la clave del arco es símbolo parlante de esta voluntad real.

La Capilla Real culminaría, por tanto, su aspiración de legitimación. Concebida para enterramiento de su padre, Alfonso XI, y de su abuelo, Fernando IV, se halla contigua al lucernario de al-Hakam II -capilla de Villaviciosa-, donde estuvo el altar mayor desde la conquista cristiana hasta la construcción de la nueva capilla mayor, crucero y coro $^{21}$. Se subraya, así, el espacio camino entre la puerta del Perdón y la capilla mayor, quedando el enterramiento real justo por detrás de esta última y convirtiéndose la intervención de Enrique II en un palmario ejemplo del uso de la arquitectura con carácter propagandístico, al perseguir al mismo tiempo justificar la legitimación del Trastámara como sucesor al trono, dado su origen bastardo, y proporcionar la seguridad de una política continuista ${ }^{22}$, refrendada por el programa pictórico prácticamente desaparecido de la capilla de Villaviciosa y de la propia Capilla Real, que ha sido analizado por Laguna Paúl ${ }^{23}$.

La inscripción que recorre el arco apuntado de la puerta del Perdón confirma lo anterior: "[...] DIA DOS DEL MES DE MARCO DE LA ERA DE CESAR DE MILL ET QUATROCIENTOS ET QUINÇE AN/NOS RREYNA[N]TE EL MUY ALTO ET PODERO[SO] DON ENRRIQUe REY dE CASTILLA ET FIIO DEL MUY ALTO REY DON ALFONSO [...]”24. Es, por consiguiente, una proclamación de legitimidad rubricada por el soberano, quien, además, se presenta a sí mismo como defensor de la fe. Dios lo ha elegido para alejar el mal y así, la inscripción del alfiz, tomada de Completas del Breviario Romano, reza: "Uysyta quesumus domyne habytacionem i[s]tam et omnes insydyas inymicy ab ea longe repelle; angely tuy sancty hab [i]tantes in ea nos in pacem (sic) custodiant et benedictio tua sit super nos semper" ${ }^{25}$. Por este motivo, la

${ }^{21}$ Una interpretación del lucernario y su entorno que rompe con la historiografía tradicional en RUIZ SOUZA, J. C.: "La fachada luminosa de al-Hakam II en la mezquita de Córdoba. Hipótesis para el debate", Madrider Mitteilungen, 42, 2001, pp. 432-445.

${ }^{22}$ Aunque proclamó su intención de proseguir la línea de su padre, Alfonso XI, la realidad fue que a la larga creó un nuevo Estado. PASCUAL MARTÍNEZ, Lope: "Itinerario andaluz de Enrique II de Castilla" en Actas del I Congreso de Historia de Andalucía, Andalucía Medieval. Córdoba, 1976, t. 2, p. 198.

${ }^{23}$ LAGUNA PAÚL, Teresa: "Dos fragmentos en busca de autor y una fecha equívoca. Alonso Martínez, pintor en Córdoba a mediados del siglo XIV, y las pinturas de la capilla de Villaviciosa", Laboratorio de Arte, 18, 2005, pp. 81-86.

${ }^{24}$ Orti Belmonte y Nieto Cumplido completan la frase por el principio y final respectivamente (ORTI BELMONTE, Miguel Ángel: La catedral - antigua mezquita y santuarios cordobeses. Córdoba, 1970, p. 189; NIETO CUMPLIDO, Manuel. La catedral..., op. cit., p. 606).

25 "Visita, Señor, esta habitación: aleja de ella las insidias del enemigo; que tus santos ángeles habiten en ella y nos guarden en paz, y que tu bendición permanezca siempre con 
portada tiene un doble mensaje: político y religioso, que se entiende en su cabal concepción apoyado en el arco de Bendiciones y culminando en la Capilla Real, que completaría el eje Perdón-Bendiciones-Villaviciosa. No dejó pasar el Trastámara la ocasión de perpetuar su memoria en dicha capilla, donde dispuso otra leyenda acompañando su retrato, hoy desaparecido: "este es el muy alto rrey $d$. Enrique. Por onra del cuerpo del rrey su padre esta capiella mando facer acabose en la era de M e CCCCIX años".

Al no tratarse de intervenciones aisladas, es importante tener en cuenta las fechas en que se erige la Capilla Real (1371) y la renovación de la puerta del Perdón (1377). El año 1371 fue especialmente favorable al soberano: logra firmar la Paz de Alcutín con Portugal, Zamora se rinde tras el cerco al que la somete la reina doña Juana Manuel y Carmona cae tras dos años de resistencia. Acababa así con los dos focos partidarios de Pedro I. Fue decisivo el aplastamiento de la villa andaluza, pues prácticamente era el único bastión legitimista en el sur. Su defensor era el maestre de Calatrava, Martín López de Córdoba, a quien Enrique II mandó ejecutar ${ }^{26}$. El maestre había sido el único noble de la ciudad cordobesa que no se había mostrado partidario del Trastámara. Estas circunstancias debieron ser claves para que Enrique II eligiera la catedral de Córdoba como el lugar donde desplegaría su programa propagandístico, pues, salvo el maestre, la ciudad le había mostrado su apoyo incondicional. En esta elección del soberano contribuyó, asimismo, el deseo de su padre, Alfonso XI, de que le enterraran allí, para lo cual Enrique erigió la Capilla Real, trasladando el cuerpo desde la catedral de Sevilla justamente en este año propicio de 1371.

Este magno proyecto no concluyó bajo su reinado. Redobló su afán de mantener la paz peninsular en los últimos años de su reinado con una política matrimonia ${ }^{27}$. El carácter escenográfico de la portada siguió vigente bajo su hijo Juan I, quien dispuso en las albanegas los escudos que revelaban su estratégico entronque con Beatriz, hija de Fernando I de Portugal, en 1383 (Figura 2) ${ }^{28}$. La derrota

nosotros". La faja vertical derecha del alfiz conserva restos de una oración latina: “(...) lucem (...) concede perpetuam. Per dominum n[os]tr[um] iesum Xp [istu]m fil”. NIETO CUMPLIDO, Manuel. La catedral..., op. cit., p. 609.

${ }^{26}$ NIETO CUMPLIDO, Manuel. La catedral..., op. cit., p. 202. Crónicas de los Reyes de Castilla. Madrid, 1877, t. 2, p. 8. http://bibliotecadigital.jcyl.es/i18n/catalogo_imagenes/grupo.cmd?path=10073454. Consultado el 5/07/2015. VALDEÓN BARUQUE, Julio: Enrique II, 1369-1379. Palencia, 1996, pp. 97-113.

${ }^{27}$ PASCUAL MARTÍNEZ, Lope: “Itinerario andaluz...”, op. cit., pp. 203-204. El rey murió en 1379.

${ }^{28}$ MOLINERO MERCHÁN, Juan Andrés: La Mezquita-Catedral de Córdoba: Símbolos de poder. Estudio histórico-artístico a través de sus armerías. Córdoba, 2005, pp. 188194. JORDANO BARBUDO, Ma Ángeles: Escudos de Córdoba y provincia en fachadas y portadas. Córdoba, 2012, pp. 57-58. 
en Aljubarrota (1385) quebró las aspiraciones de Juan I de sumar Portugal bajo su corona. Su fallecimiento en 1390 sirve para fijar el ante quem de esta intervención que se limitó a superponer a la decoración preexistente las armas reales, si bien mediante este significativo gesto rubricaba la declaración epigráfica de su padre. Con esta aportación heráldica, el conjunto del Perdón terminaba por adquirir no solo la apariencia, sino la función de portada áulica, eclipsando así los símbolos sagrados, reducidos a algunas de las inscripciones y escudetes con la cruz que decoran las hojas broncíneas de la puerta.

\section{PRECEDENTES TIPOLÓGICOS Y DESCRIPCIONES}

El aspecto actual de la puerta dista del que debió tener en origen si atendemos a la fuente principal para conocer su imagen primitiva: el escudo del cabildo en la puerta de Santa Catalina (ca. 1565) (Figura 3), la segunda en importancia, reservada para los actos de carácter religioso, tanto litúrgicos como devocionales ${ }^{29}$.

El precedente arquitectónico son las puertas de aparato almohades, sobre todo en la arquitectura civil, si bien el paralelismo más cercano es la homónima puerta almohade de la aljama sevillana. El paradigma lo ofrece la Qasba de los Udaia en Rabat, aunque su complejidad es mayor por tener varias cámaras cubiertas con distintos tipos de bóvedas entre los dos arcos, siendo definida como la "majestuosa galería de palacio"”30; por tanto, el esquema empleado en las dos urbes andaluzas estaría entre los más simples ${ }^{31}$.

La influencia de la portada sevillana en el ejemplar cordobés se hace notar en su concepción en resalte respecto al muro exterior, el antiguo remate en andén de merlones escalonados y la disposición entre contrafuertes como ya sostenía Terrase $^{32}$. Cabría suponer, según él, que la portada original sevillana estaría culminada por el mismo andén que recorre la fachada. En Córdoba, el escudo de la fábrica de la catedral en la puerta de Santa Catalina arroja luz sobre el aspecto primigenio, pudiéndose apreciar el tejaroz que protegía la portada y que sabemos estuvo presente en la catedral de Sevilla hasta $1838^{33}$ y en la mezquita de los Andaluces en Fez.

${ }^{29}$ NIETO CUMPLIDO, Manuel: La Catedral..., op. cit., p. 611. MOLINERO MERCHÁN, Andrés: La mezquita-catedral..., op. cit., pp. 314-315.

${ }^{30}$ HOAG, John D.: Arquitectura islámica. Madrid, 1976, p. 114.

${ }^{31}$ Es interesante observar cómo en la Capilla Real se procedió a cerrar sus lados norte y sur mediante un sistema parecido: dos grandes arcos en paralelo dejan un espacio central para recibir la bóveda.

32 TERRASSE, Henry: "La grande mosquée almohade de Séville", Memorial Henri Basset. París, 1928, t. 2, p. 258. CÓMEZ RAMOS, Rafael: "La puerta principal de la aljama almohade de Sevilla", Archivo Hispalense, 2012, t. 95, n 288-290, p. 200.

33 CÓMEZ RAMOS, Rafael: "La puerta principal...", op. cit., p. 200. 
Tras el arco principal y a corta distancia se halla otro arco creándose un breve tramo que en la actualidad aparece cubierto con fragmento de bóveda de cañón barroca; espacio suficiente para que cupieran las hojas de la puerta una vez abiertas. Más allá se encuentra el espacio central de planta cuadrada que, si bien hoy aparece con cúpula barroca, originalmente pudo tener una bóveda de mocárabes dorados, seguramente de época de Enrique II, que rivalizaría con la de la Capilla Real de 1377.

En 1572 Ambrosio de Morales describía así la puerta:

"El arco es morisco, con brotantes sobre los pies derechos, con que se pierde el medio punto y se va a hacer círculo, como vemos muchos arcos de Godos y de Moros. Las puertas están cubiertas de bronce, y relevados por todas ellas unos artesones menores que una mano, y labrados de unos follages muy delicados con mucha costa y detenimiento. Las aldabas son dos grandes florones fundidos de bronce. Todo el ornato de la portada es de estuco labrado muy menudo, y por lo alto están seis colunas, que hacen cino nichos, donde agora están imágenes de pincel. Estas seis colunas son gruesas más que el muslo, $y$ de un estado en alto. Su valor es inestimable, por ser todas de turquesa finísima; y ansi han puesto amiración a muchos artifices extrangeros, que afirman no hallarse en Roma ni en otra parte colunas que se puedan comparar con éstas en ser tan preciosas. Cerca de Zamora y en Galicia hay vena de turquesa, mas no para sacarse mas que muy pequeños pedazos, Así se entiende, como se truxeron estas columnas de muy lejos de Grecia, o del Oriente" ${ }^{34}$.

Cabría poner en cuestión la afirmación de que hubo cinco nichos sobre seis columnas. Efectivamente, hay cinco arquillos, pero no juntos, sino tres en la parte central y dos en los contrafuertes o machones que flanquean la portada y que encontrarían réplica en los que flanquean el arco de Bendiciones, los cuales son de la misma cronología, mudéjares y con lóbulos encintados, igual que en el Perdón. En cuanto a los capiteles, aunque Nieto afirma que deben proceder del alminar ${ }^{35}$, lo cierto es que el izquierdo es corintio y labrado con trépano; los otros tres, compuestos, son semejantes entre sí y no hemos encontrado paralelos en todo el conjunto. Los fustes de los extremos están policromados en azul y quizá por eso A. de Morales dijera que eran de turquesa.

En el Archivo de la Catedral de Córdoba se conserva la descripción del templo realizada por Tomás Fernández Moreno en $1744^{36}$, quien se centra en su uso

${ }^{34}$ MORALES, Ambrosio de: Las antigüedades de las ciudades de España. Madrid, 1792, t. 10, pp. 66-68. http://www.bibliotecavirtualdeandalucia.es/catalogo/consulta/registro.cmd?id=1020130. Consultado el 12/08/2015.

${ }^{35}$ NIETO CUMPLIDO, Manuel: La Catedral..., op. cit., p. 170.

${ }^{36}$ FERNÁNDEZ MORENO, Tomás: Relación de las cosas notables del templo material de la Santa Yglesia de Cordova, 1744, inédito, A.C.C. (Archivo de la Catedral de Córdoba), s.s. Agradezco a don Manuel Nieto Cumplido, canónigo archivero de la catedral de Córdoba, el haberme facilitado su consulta. 
protocolario, haciendo hincapié en el ceremonial con motivo del nombramiento de un nuevo obispo:

"Por los tres costados de este templo ay quince puertas. La principal se llama del Perdón, como dice el P. Roa en el Flos Sanctorum de Cordova tratando de la dedicación de la Yglesia y por las copiosas indulgencias que en ella se ganan. En esta puerta hacen los Señores obispos el juramento quando el cavildo los recive y hecho va siguiendo la procesión a entrar por el Arco de Bendiciones llamado así por las que el obispo echa quando pasa por él despues de recevido"37.

Asimismo, llama su atención la decoración de las puertas:

"[...] digo que esta elevada puerta está forrada toda de planchas de bronce fino, y labrada la circunferencia de sutil estuco ${ }^{38}$ y como dice el P. Martín de Roa en el citado Flos Sanctorum tiene muchas letras Gothicas, en alabanzas de Dios [...] Y por toda la puerta en las planchas de arriba avajo repite en cada una: Bendito sea Dios" ${ }^{\prime 39}$.

Al hacer la descripción de una tormenta ocurrida el 24 de agosto de 1727 y de un rayo que cayó sobre la torre ocasionando varios daños, refiere que dicho rayo

"sacó de el arco, corona de la Puerta del Perdón, una piedra, y quitó todo el encalado circular de la ymagen de María Santísima, que está en el arco mismo, dejándole el rostro sin lesión, y la circunferencia de la Ymagen llena de humo, tocando también el umbral de la puerta, a el qual, grueso Pino de Alerce, lo cascó, e hizo rafas: baxó a la solería de la Puerta de el Perdón, levantó dos piedras de jaspe blanco delgadas de tres quartas de largo cada una, dejando en sus sitios toda la cal, con que estavan apretadas, sin mover a las compañeras, y el demonio parece se las llevó porque ellas ni se vieron más, ni han parecido, habiéndolas buscado con diligencia y cuidado. Quatro muchachas estaban dormiendo en las gradas de la calle: dispiertas con el asombro, se metieron dentro de la Puerta de el Perdón (ya abierta) acogiéndose debaxo de la Santa Cruz negra que allí ay [...]. Reparada ya la torre, entró a ser Obispo el Señor Dn. Pedro de Salazar y Gongora, y para mayor adorno de la puerta principal de la Yglesia mandó quitar las puertas, que estaban ya lastimadas de el tiempo, para repararlas, haciendo también nuevamente la bóveda toda de fina talla de yeso, colocando en ella sus armas, todo lo qual se acabó el año de 1740"40.

${ }^{37}$ FERNÁNDEZ MORENO, Tomás: Relación de las cosas..., op. cit., fol. 227r.

${ }^{38}$ Amplía algo más su descripción: "[...] y labrada en su contorno de arriva abaxo de eiusco (sic) fino y sutil, y muchas letras arábigas y góticas en alabanza de Dios”. MORENO, Tomás: Extracto de la sucinta descripción de la ynsigne Yglesia Mayor Cathedral de la ciudad de Cordova. Hecha por el Lizenciado Dn. Thomas Moreno, su capellán [...], 1760, s.f., A.C.C., s.s.

39 FERNÁNDEZ MORENO, Tomás: Relación de las cosas notables..., op. cit., fol. 228r.

${ }^{40}$ FERNÁNDEZ MORENO, Tomás: Relación de las cosas notables..., op. cit., ff. $304 \mathrm{v}-307 \mathrm{v}$. 


\section{ESTRUCTURA TRIPARTITA DE LA PORTADA}

Parece evidente que el modelo que inspiró la composición tripartita de la portada pudo ser la puerta de San Sebastián de la aljama cordobesa bajo Abd alRahman I. Su repercusión es sobradamente conocida y su influencia alcanzó a numerosas fachadas de mihrabs y portadas. Sus fuentes de inspiración están en Roma y Bizancio, en las puertas monumentales o arcos de triunfo ${ }^{41}$. De la culminación del esquema con un friso corrido de arquillos, desaparecido tras la reforma del XVII, es testigo el escudo de la obra de la catedral.

La parte central de la puerta del Perdón, con las lógicas adaptaciones al cambio de estética, mantiene el esquema de arco principal enmarcado por alfiz, faja de tres arcos ciegos decorativos y tejaroz - hoy desaparecido por la adición del relieve con la representación de Dios Padre, así como la construcción de la casa del campanero-, pero de cuya envergadura nos podemos hacer una idea gracias al escudo de la fábrica de la catedral en la puerta de Santa Catalina y, de forma más real, gracias al de la homónima puerta sevillana o la de Montería en el Alcázar. Las calles laterales de la portada de Abd al-Rahman I se reflejan en la mudéjar mediante la decoración de los contrafuertes con arcos ciegos lobulados ${ }^{42}$, tipo que repetirá Enrique II en el arco de Bendiciones y la Capilla Real.

Los tres arcos lobulados centrales se hallan cobijados por un gran arco de medio punto, fruto de la reforma del siglo XVII. Posiblemente este arco, cuya función es la de descarga, ya existía con otro aspecto en la primitiva portada islámica, pues aunque es más propio de fortalezas y murallas, se encuentra, por ejemplo, en los arcos exteriores del patio de los Naranjos de Sevilla ${ }^{43}$.

\section{METALISTERÍA. DECORACIÓN DE LAS HOJAS DE BRONCE}

La puerta se cierra mediante dos hojas constituidas por maderos de pino cubiertos con placas de bronce de fundición que forman una decoración de lacería acompañada de inscripciones árabes en cúfico y latinas en escritura gótica, además de escudos con la cruz (Figura 4). Se fechan en 1377 por inscripción y están relacionadas con las almohades de la puerta homónima de la catedral de Sevilla.

Los trabajos de restauración llevados a cabo en 1997-1998 a causa del estado de corrosión del metal pusieron de manifiesto que las planchas que guarnecen los cantos de las hojas y el resto de piezas son de bronce de distinta aleación

${ }^{41}$ PAVÓN MALDONADO, Basilio: Tratado..., op. cit., t. 2, pp. 401-402, 393-395. PAVÓN MALDONADO, Basilio: Tratado..., op. cit., t. 2, pp. 395-396.

${ }_{42}$ Aún conservan en las albanegas restos de azulejos vidriados en verde.

${ }^{43}$ PAVÓN MALDONADO, Basilio: Tratado..., op. cit., t. 2, pp. 399-400. 
y fechables en tres épocas diferentes ${ }^{44}$. Aparecieron las marcas de buril que en el fondo de las placas dibujan trazos de círculo simple o doble círculo concéntrico, así como las producidas al trabajar el artista las molduras que enmarcan las placas ${ }^{45}$.

La lacería que conforma la decoración se debe a una estrella de cuatro puntas rodeada de cuatro hexágonos rectangulares o alfardones, dispuestos alternativamente en horizontal y vertical. Este esquema compositivo deriva de mosaicos de la Antigüedad, en los que se alternaban formas rectangulares con pequeños cuadrados. De ahí pasó al arte islámico, donde se convirtió en tema frecuente en solerías, para desde allí transformarse en la red de hexágonos irregulares y estrellas de cuatro puntas que se aplicó en múltiples soportes. Pavón Maldonado ha seguido la evolución cronológica de dicho diseño desde sus orígenes en las yeserías de la mezquita de Ibn Tulún, pasando por la decoración pictórica de la techumbre de la mezquita de Qayrawan en el s. XI y alcanzando su máxima difusión en el arte nazarí (p.e. zócalos pintados del Peinador bajo en la Alhambra), aunque también estuvo presente en el arte medieval cristiano peninsular, como en miniaturas de las Cantigas, en alicatados del monasterio de Poblet, en la solería de la capilla bautismal de Santo Domingo de Carmona, y en soporte cerámico, como es el caso de un sepulcro de la sinagoga del Tránsito ${ }^{46}$. Sin embargo, el paralelismo más estrecho se produce entre la puerta del Perdón de Sevilla, de época almohade, y la de Córdoba, de estilo mudéjar.

Los alfardones horizontales llevan la inscripción cúfica "De Dios es el imperio de todo"; los verticales, una cruz latina en cuyos cuarteles figuran las letras $d$-e-u-s (Dios). El resto de la superficie se cubre con palmetas. Destacan dos alfardones en los que se lee "Se reedificaron", refiriéndose a las puertas, y "AÑO 1739”, que sitúa dicha restauración en el episcopado de don Pedro Salazar y Góngora.

Otra pieza geométrica es el azafate o figura poligonal de cinco lados, decorado con pequeñas palmetas ligadas mediante roleos. Elemento básico en esta lacería es la estrella de cuatro puntas, que puede aparecer con una chilla avenerada en su centro y decoración geométrica o con palmetas y roleos. Una cenefa

${ }^{4}$ Proyecto y Memoria. Limpieza y consolidación de la Puerta del Perdón. MezquitaCatedral. Córdoba. Tratamientos de Conservación y Restauración, S.L. Junta de Andalucía, Consejería de Cultura, s.f. 2 t. 1997-1998. A.C.C., Caj. 8, nº 40. Los trabajos comenzaron en enero de 1998. Pocos años antes fueron respuestas algunas piezas de la zona inferior de las hojas.

${ }^{45}$ Proyecto y Memoria. Limpieza..., op. cit., p. 4.

46 PAVÓN MALDONADO, Basilio. El arte hispanomusulmán en su decoración geométrica. (Una teoría para un estilo). Madrid, 1989, pp. 351-354. PAVÓN MALDONADO, Basilio. Tratado de arquitectura hispanomusulmana, Mezquitas. Madrid, 2009, t. 4, p. 560. 
perimetral recorre la puerta con la inscripción en caracteres góticos que repite "bendito sea el nombre de Dios"

Los aldabones, que denotan estrecho parentesco con los sevillanos, llevan la siguiente inscripción: "Benedictus Dominus Deus Israel quia visitavit et fecit redemptionem plebis suae” (Figura 5) ${ }^{48}$. La misma fue utilizada antes de la realización de estos cordobeses, hacia 1275, en el friso de yeserías que recorre el arranque de la bóveda del paso que comunica el claustro de San Fernando con las Claustrillas en Las Huelgas de $\operatorname{Burgos}^{49}$, mientras la bóveda ostentaba reiteradamente el escudo de Castilla. En ambos casos, tanto el burgalés como el cordobés, se repite la circunstancia de ser, más que lugares de paso de las procesiones litúrgicas, el punto que marcaba el tránsito desde lo terrenal hacia lo sagrado. No en vano, la sala de paso de las Huelgas conectaba con la capilla de la Asunción y la de Santiago. La primera fue utilizada por Alfonso VIII y Leonor de Plantagenet como lugar de enterramiento ${ }^{50}$ hasta su traslado a la iglesia abacial. Eso explicaría la representación recurrente del escudo real en este paso del monasterio. En la Puerta del Perdón las armas del rey están en la clave y en las albanegas del arco.

La elección de la inscripción pudo obedecer a la intención de alejar el mal, como las imágenes que se han utilizado a lo largo de la historia con carácter apotropaico -la propia mano de Fátima en la puerta de la Justicia de la Alhambra, en opinión de algunos-, aparte, evidentemente, de ejercer su funcionalidad como epígrafe parlante en un lugar donde el ritual litúrgico y ceremonial con significado religioso y político cobraba todo su sentido y en el que la escritura reforzaba el uso protocolario de la arquitectura a modo de topografía simbólica.

${ }^{47}$ Con motivo de la intervención de 1739 se produjo una alteración en la colocación de bastantes piezas, disponiéndose algunas con el texto invertido, mientras que otras fueron cambiadas de hoja. Proyecto y Memoria. Limpieza..., op. cit., t. 1, p. 4. Dimensiones de cada hoja: $740 \mathrm{~cm}$ x $195 \mathrm{~cm}$. Los cantos van revestidos con chapas de bronce de $1 \mathrm{~mm}$ de espesor. Cada trozo mide entre 15 y $20 \mathrm{~cm}$. Se solapan entre sí hasta los 10-15 cm por el trasdós y se sujetan mediante clavos del mismo metal. Todas estas piezas van rodeadas de una moldura en junquillo para enmarcarlas y, a su vez, sirven para soportar los clavos de hierro remachados por el revés de la puerta y que sustituyeron a los originales de bronce, de los que aún quedan algunos.

48 "Bendito sea el Señor, Dios de Israel, porque visitó y rescató a su pueblo". Cita extraída del cántico de Zacarías, del Evangelio de San Lucas. ORTI BELMONTE, Miguel Ángel: La catedral..., op. cit., p. 190.

${ }^{49}$ CARRERO SANTAMARÍA, Eduardo: "Liturgia estacional entre el locutorio y el pasaje a la enfermería de la abadía de Santa María la Real de las Huelgas, en Burgos", Territorio, Sociedad y Poder, 9, 2014, pp. 128-130.

${ }^{50}$ SÁNCHEZ ARMEIJEIRAS, Rocío: "El "çementerio real” de Alfonso VIII en Las Huelgas de Burgos", Semata, 10, 1998, pp. 77-109. 


\section{LAS YESERÍAS MUDÉJARES ${ }^{51}$}

Aunque la nota dominante es la estética mudéjar en la ornamentación en yeso de la portada, aún se aprecian dos pequeños fragmentos de la decoración vegetal realizada en piedra en época islámica, probablemente bajo Abd al-Rahman III, que se encuentran en el alfiz (Figura 6). Estos motivos quedan en un nivel de profundidad ligeramente por debajo de los yesos mudéjares, por lo que parece que estos artistas no picaron lo original, sino que se limitaron a lanzar, fratasar y decorar el yeso encima del califal.

Los maestros yeseros que trabajaron aquí en 1377 están estrechamente relacionados con los que realizaron el arco de pabellón que alberga el altar de la Capilla Real. El carácter naturalista de los motivos vegetales (hoja de roble y vid) enlazan especialmente con el mudéjar de Toledo. Pérez Higuera ha defendido el protagonismo del foco toledano como centro activo y transmisor, incluso hacia Andalucía, como ejemplifican el Alcázar de Sevilla ${ }^{52}$ y la Alhambra. Es una vegetación que introducía una nota cristianizada en el abstracto universo del ataurique. Su presencia en lugares por lo general preeminentes nos lleva a plantear que en su elección fue determinante la intención de realzar un lugar de privilegio.

\section{LAS PINTURAS DE ANTONIO DEL CASTILLO Y EL DIBUJO DEL MUSEO DE BELLAS ARTES}

Gracias a un dibujo conservado en el Museo de Bellas Artes, atribuido por la mayoría de especialistas a Antonio del Castillo Saavedra (1616-1668) ${ }^{53}$, es posible conocer el proyecto fechado en 1651 que ideó este importante artista cordobés ${ }^{54}$, bajo la dirección de su comitente, fray Pedro de Tapia, obispo de Córdoba (1649-1652), con el fin de modificar la apariencia de la puerta del Perdón que, de haberse llevado a cabo, únicamente hubiera dejado visible de la obra de Enrique II el arco apuntado (Figura 7). En el dibujo se aprecia la transformación total de la puerta para adaptarla a la estética del momento. El escaso intervalo que estuvo ocupando la silla episcopal fray Pedro de Tapia, quien firma y rubrica el proyecto de Castillo, hace pensar que no dio tiempo a ejecutarlo en su totalidad. El

${ }^{51}$ Información más extensa en JORDANO BARBUDO, Ma Ángeles. La Sinagoga..., op. cit., pp. 162-167.

52 PÉREZ HIGUERA, Ma Teresa: “Toledo Mudéjar" en Arquitecturas de Toledo. Del Romano al Gótico. Toledo, 1992, p. 82.

${ }_{53}$ Fundamentalmente P. Muller, cit. por VALVERDE CANDIL, Mercedes: "Los dibujos de Antonio del Castillo Saavedra", en Antonio del Castillo y su época. Córdoba, 1986, p. 113. GARCÍA DE LA TORRE, Fuensanta: Dibujos del Museo de Bellas Artes de Córdoba. Sevilla, 1997, pp. 96-99.

${ }^{54}$ GARCÍA DE LA TORRE, Fuensanta: Dibujos..., op. cit., p. 91. 
fallecimiento del mecenas debió frustrar su culminación, pero qué duda cabe que fue un factor decisivo para la conservación de la fábrica enriqueña.

El dibujo revela la concepción de la puerta a modo de gran retablo pictórico $^{55}$. Castillo respeta el soporte arquitectónico y diseña, por encima del arco de herradura apuntado medieval, un medio punto que alberga la Asunción, flanqueada, en un nivel inferior, por San Acisclo y Santa Victoria, mártires romanos y patronos de la ciudad. Bajo la Virgen, dos leones rampantes sostienen un escudo que, por la presencia de los animales y la previa existencia de las armas del rey, es presumible que se tratara del blasón real. La calle central culmina con un entablamento, interrumpido en su centro para acoger a Dios Padre, que ha sido relacionado con Bernabé Gómez del Río ${ }^{56}$. Los machones que escoltan la portada fueron adaptados como pilastras para soportar el citado remate, mientras que en sus frentes parece que Castillo quiso aprovechar los cuatro arcos lobulados mudéjares, transformándolos en hornacinas fingidas para acoger en el registro inferior las pinturas de San Rafael y San Gabriel y en el superior a San Pedro y San Pablo. Entremedias irían sendos escudos, posiblemente destinados a lucir las armas del obispo patrocinador.

Es de notar la conversión ideológica y formal de una puerta de aparato medieval, de carácter protocolario y claramente propagandística y legitimadora del soberano Trastámara, en una entrada concebida a modo de grandioso retablo efectista, donde se exalta la Asunción de la Virgen María, cuya advocación adopta la catedral a partir del siglo $\mathrm{XVI}^{57}$ siguiendo los postulados postrentinos, así como el protagonismo de los mártires y los arcángeles: San Rafael, custodio de Córdoba, al que se le atribuía la recuperación milagrosa de la población de la terrible peste de 1649, aún muy reciente ${ }^{58}$, y San Gabriel ${ }^{59}$.

La elección de los apóstoles Pedro y Pablo, pilares de la Iglesia, estaría justificada por la conquista de la ciudad un 29 de junio, pero quizá también pesó en ello el que por entonces fuera obispo de Córdoba el dominico fray Pedro de Tapia

${ }^{55}$ Sobre la idea inicial de un retablo compuesto exclusivamente por pinturas, sin incluir esculturas, véase GARCÍA DE LA TORRE, Fuensanta: Dibujos..., op. cit., p. 98.

${ }^{56}$ VILLAR MOVELLÁN, Alberto (Dir.): Guía artística de la provincia de Córdoba. Córdoba, 1995, p. 21.

${ }^{57}$ NIETO CUMPLIDO, Manuel: La catedral..., op. cit., p. 335.

${ }^{58}$ El obispo fue especialmente sensible con los apestados (GÓMEZ BRAVO, Juan: Catálogo de los obispos..., op. cit., t. 2, p. 656 y ss.).

59 Ya que la Asunción ocupaba el centro, este arcángel pudiera evocar la Anunciación. De ser cierta esta hipótesis, se justificaría porque habría la intención de traer el programa redentorista de la catedral a la puerta del Perdón. Sobre dicho programa, véase MORENO CUADRO, Fernando: El crucero de la catedral de Córdoba. Estudio iconográfico e iconológico. Cuadernos de Arte e Iconografía, XVI, 31, Madrid, 2007, pp. 30-36. La presencia de María no se debe solo a ser la titular del templo, sino a que fue un momento especialmente importante en relación con la Virgen. 
(1649-1652), quien honraba así a quienes exhortaron a Santo Domingo de Guzmán, fundador de la Orden de Predicadores, a realizar una prédica itinerante. No menos lo estaría la de San Rafael, cuya aparición al Padre Roelas -la más reciente en 1578- anunciándole que protegería a la población, desencadenó, con motivo de la plaga de 1649, una calurosa devoción al custodio. El propio Castillo ganó el concurso de poesía dedicado a la exaltación de San Rafael en 1651, en el cual decía refiriéndose al arcángel: "Antídoto del aire se coloque / del Templo Catedral en lo eminente, I mi Imagen, y frecuente mi devoción el pueblo, a quien provoque su prelado, obediente: dijo, y entre esplendores, batió el vuelo, y obedecido serenose el cielo" ${ }^{\prime}$. En el puente romano se erigió su estatua, realizada por Bernabé Gómez del Río ese mismo año, amigo y escultor con el que trabajó en diversas ocasiones A. del Castillo ${ }^{61}$ y a quien se le ha atribuido el relieve del Padre Eterno de la por$\operatorname{tada}^{62}$. Los encargos con la imagen del custodio llovieron sobre Castillo, quien realizó el del Ayuntamiento en 1652. Uno de los bocetos que trazó para esta obra serviría a Pedro de Paz para hacer en 1664 la escultura que culmina la torre ${ }^{63}$.

El conjunto de pinturas al fresco llegó al siglo XX muy deteriorado (Figura 8). A pesar de que Antonio Álvarez Torrado las restauró a fines del XVIII ${ }^{64}$, hoy solo se reconoce a San Rafael, San Gabriel, la Asunción y los ángeles que coronan esta imagen, que han sido relacionados con otros de Castillo ${ }^{65}$.

La culminación del programa tendría lugar con la realización del relieve dedicado a San Miguel en el lado que mira al patio bajo el episcopado de Miguel Vicente Cebrián (1742-1752) ${ }^{66}$, imagen atribuida a Juan Fernández del Río ${ }^{67}$.

\section{LA CÚPULA BARROCA}

La construcción de una cúpula en la puerta del Perdón en 1740 se debió al obispo don Pedro de Salazar y Góngora (1738-1742) (Figura 9). No debe ser casual que a instancias del prelado y con la aprobación del cabildo se reparara el mismo año la atarjea que conducía el agua desde la Arruzafa a la catedral, con lo

${ }^{60}$ Texto completo en ZUERAS TORRENS, Francisco: Antonio del Castillo. Un gran pintor del barroco cordobés. Córdoba, 1982, pp. 77-79.

${ }^{61}$ GARCÍA DE LA TORRE, Fuensanta: Dibujos..., op. cit., p. 91.

${ }_{62}$ VILLAR MOVELLÁN, Alberto (Dir.): Guía artística..., op. cit., p. 21.

${ }^{63}$ ZUERAS TORRENS, Francisco: Antonio del Castillo..., op. cit., p. 79.

${ }^{64}$ VILLAR MOVELLÁN, Alberto (dir.): Guía artística..., op. cit., p. 21.

${ }^{65}$ GARCÍA DE LA TORRE, Fuensanta: Dibujos..., op. cit., p. 99. El Museo de Bellas Artes de Córdoba cuenta con varios dibujos referentes a los santos, arcángeles, ángeles y Dios Padre. VALVERDE MADRID, José: "Antonio del Castillo: su vida y su obra”, en Antonio del Castillo y su época. Córdoba, 1986, pássim.

${ }^{66}$ NIETO CUMPLIDO, Manuel: La catedral..., op. cit., p. 607.

${ }^{67}$ VILLAR MOVELLÁN, Alberto (dir.): Guia artística..., op. cit., p. 21. 
que "las aguas de las fuentes de la Iglesia se aumentaron, y con la altura que se dio al agua se hermoseó notablemente el Jardín del Patio de los Naranjos" "68. Esta mejora hay que ponerla en relación directa con su intervención en la puerta del Perdón. Su escudo en la clave de uno de los arcos torales refrendaba al obispo como el promotor de la recuperación del patio (Figura 10), símbolo del paraíso terrenal ${ }^{69}$, un vergel con sus árboles y fuentes, visión que describía en aquellos días el autor que, refiriéndose al hospital de San Juan de Dios de Lucena, decía: "entrando en el Claustro baxo, se mira un Paraíso pintado, sin que falte la Fuente, porque la tiene en su medio muy agraciada"70.

La cúpula se asienta sobre un entablamento y pechinas en las que luce el tetramorfos ${ }^{71}$. Coincidiendo con la clave de los arcos que la soportan, aparecen ángeles y querubes sosteniendo el anagrama de Cristo y el de la Virgen María ${ }^{72}$, más las armas del obispo don Pedro de Salazar y Góngora y las de la fábrica de la catedral. El escudo episcopal es el más complejo. En campo cortado: $1^{\circ}$ ) dos torres, $2^{\circ}$ ) trece estrellas, doce distribuidas en dos grupos, cada uno de ellos con tres filas de dos, y una en punta. Al timbre el capelo, del que penden los cordones y borlas indicativos de su dignidad ${ }^{73}$. Por su parte, el escudo del cabildo muestra en campo sencillo la torre de la catedral, símbolo de la institución. La ubicación de estos símbolos obedece a un meditado programa, cuyo objetivo fue potenciar la imagen del patrocinador y hacer perdurar su memoria. Su escudo se halla alineado, además, con los emblemas de Cristo y la Virgen, lo que refuerza el mensaje del prelado como representante de Dios en la tierra, formando parte de la Iglesia, simbolizada en el emblema de la catedral.

${ }^{68}$ GÓMEZ BRAVO, Juan: Catálogo ..., op. cit., p. 791.

${ }^{69}$ GÓMEZ DE AVELLANEDA SABIO, Carlos: "Patio de los naranjos: el sahn como imagen del paraíso", en Actas del II Congreso Internacional La ciudad en al-Andalus y el Magreb. Granada, 2002, pp. 709-710.

${ }^{70}$ Cit. RIVAS CARMONA, Jesús: Arquitectura barroca cordobesa, Córdoba, 1982, p. 158.

${ }^{71}$ En 2008 se llevaron a cabo una serie de catas en las yeserías de la cúpula que han descubierto la policromía previamente existente. GAMERO GONZÁLEZ, Ana Isabel: Catas en las yeserías de la cúpula barroca de la Puerta del Perdón. Catedral de Córdoba, 2008. A.C.C., Caj. 24, 168.

${ }^{72}$ Potencias y coronas reales estaban originalmente con pan de oro. GAMERO GONZÁLEZ, Ana Isabel y AGUILAR LEÓN, Manuel: Proyecto de conservación y restauración de decoraciones pictóricas en la Puerta del Perdón, s.p., 2013. A.C.C., caj. 35, 225. Id., Propuesta de restauración y acabado final de la obra. Consservación y restauración de las decoraciones pictóricas en la cúpula de la Puerta del Perdón, 2014, s.p. A.C.C., caj. 35, 225.

${ }^{73}$ MOLINERO MERCHÁN, Andrés: La mezquita-catedral..., op. cit., pp. 494-497. GÓMEZ BRAVO, Juan: Católogo..., op. cit., pp. 785-793. 
La cúpula ${ }^{74}$ aparece compartimentada en ocho secciones por guirnaldas originalmente policromadas en ocre y aplicación puntual de dorados cuya recuperación ha concluido antes de la Semana Santa de 2016 ${ }^{75}$. El maestro mayor de la catedral, Francisco Hurtado Izquierdo, sentó sólidos precedentes para esta cúpula en la capilla de Santa Teresa, iniciada en 1697 para enterramiento del cardenal fray Pedro de Salazar y Toledo, tío del prelado Pedro de Salazar y Góngora ${ }^{76}$.

Para concluir, habría que destacar la importancia de la puerta del Perdón a lo largo de los siglos desde la perspectiva que ofrece como arquitectura a modo de topografía simbólica, función que hoy sigue ejerciendo.

Fecha de recepción: 30 de septiembre de 2015.

Fecha de aceptación: 20 de noviembre de 2015.

${ }^{74}$ El hecho singular respecto a la linterna es que nunca estuvo a la vista. Por encima quedaba una bóveda de época manierista, con un acabado algo tosco, para no ser vista, trazada con objeto de contrarrestar el empuje de la portada y su coronación con el relieve de Dios Padre. Agradezco los comentarios en este sentido del arquitecto de la Delegación Territorial de la Junta de Andalucía, D. Francisco Riobóo.

${ }^{75}$ GAMERO GONZÁLEZ, Ana Isabel y AGUILAR LEÓN, Manuel: Propuesta de restauración y acabado final..., op. cit., s. p.

${ }^{76}$ Fallecido el arquitecto en 1725, pudo intervenir o dar las trazas de esta cúpula alguno de sus discípulos, como Teodosio Sánchez de Rueda (1676-1730) o el yerno de este, Tomás Jerónimo de Pedrajas. TAYLOR, René: "Francisco Hurtado and his school", The Bulletin Art, 32, 1950, p. 37. RIVAS CARMONA, J. Arquitectura ..., op. cit., p. 119. 


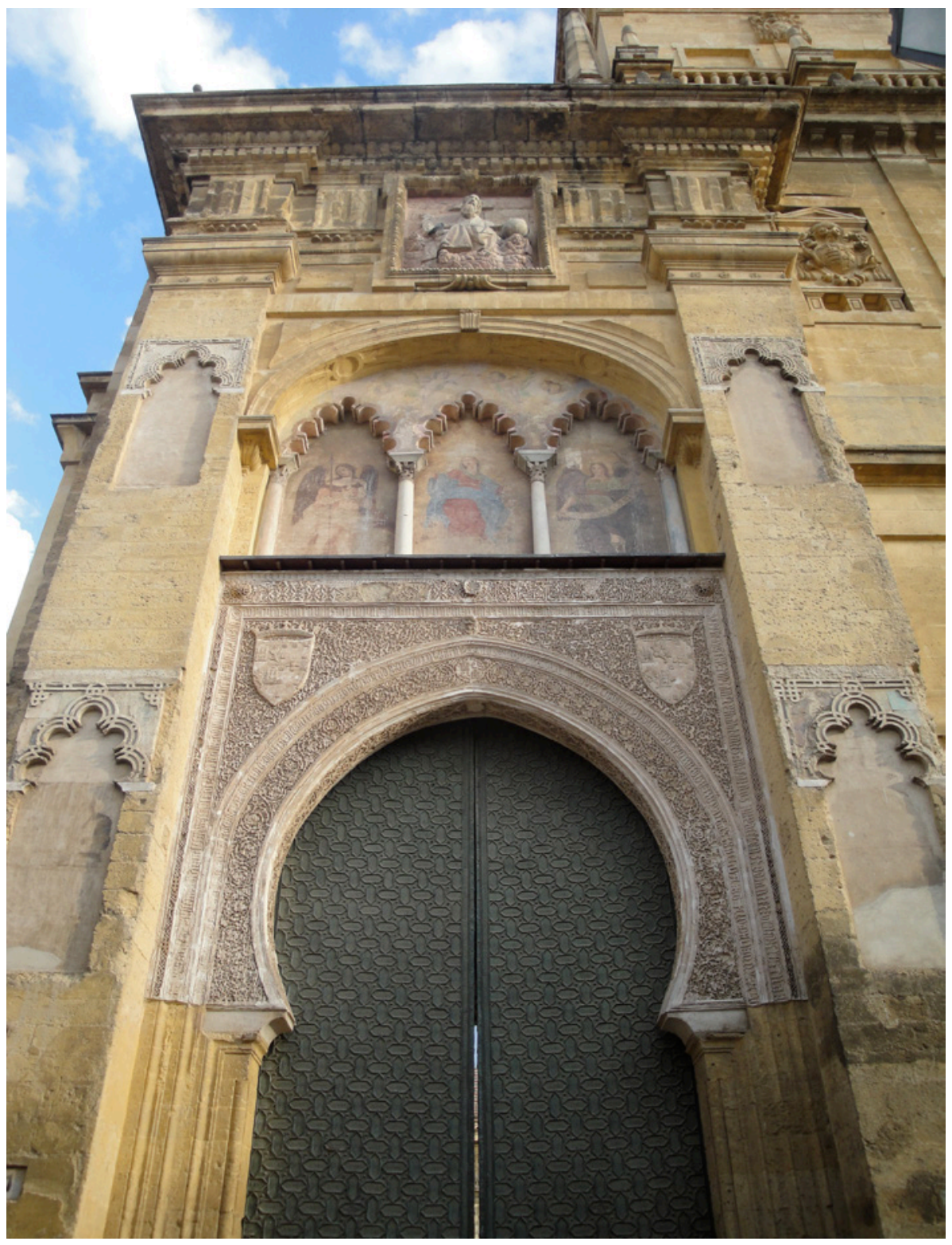

Figura 1. Puerta del Perdón, 1377. 


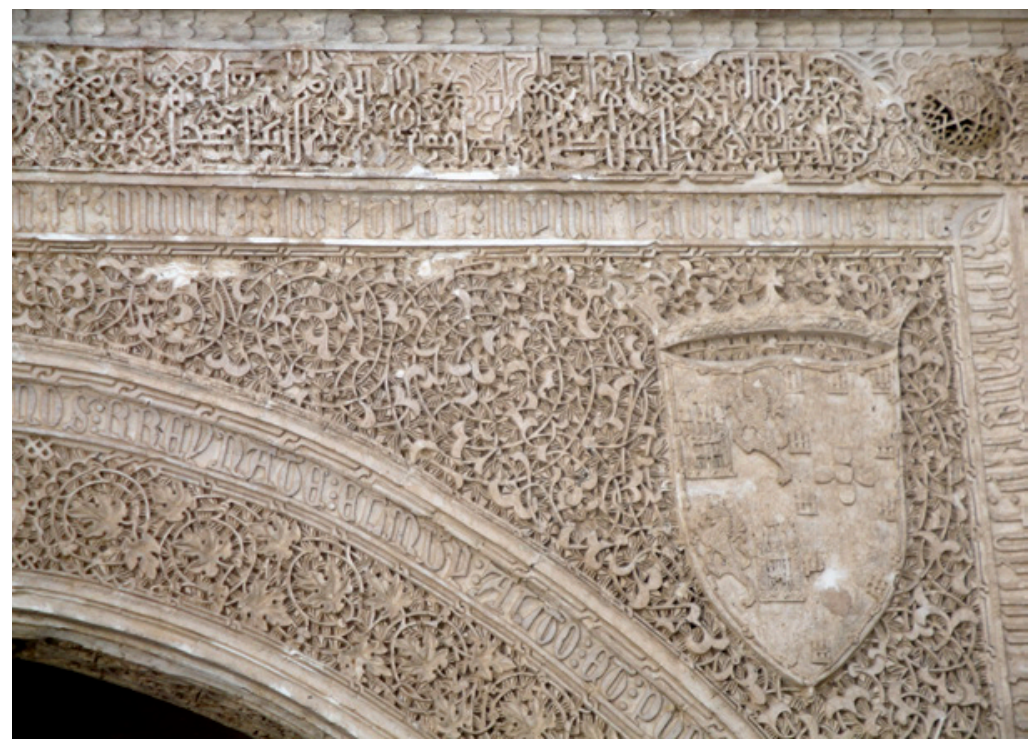

Figura 2. Escudo de Juan I de Castilla, ca. 1383.

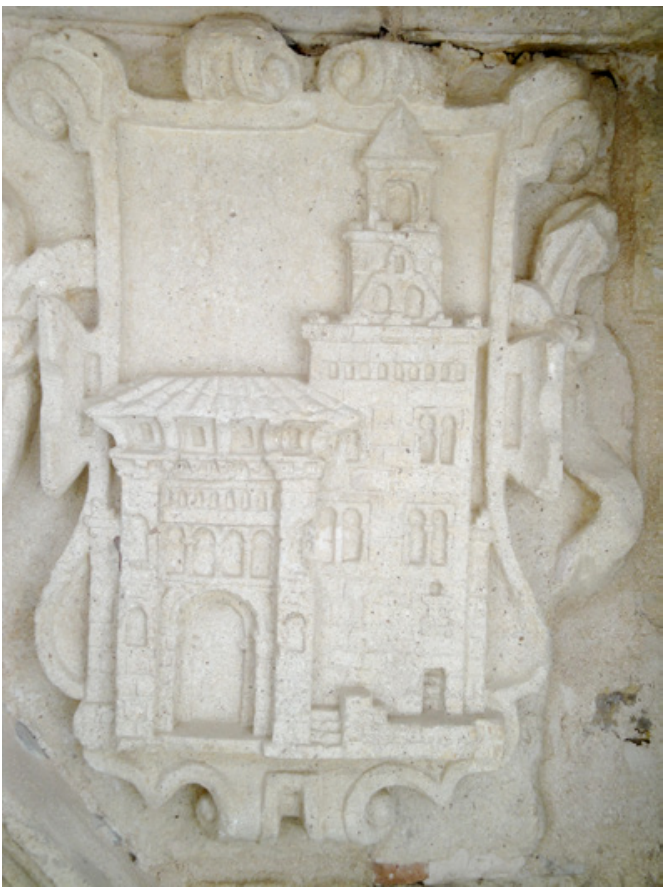

Figura 3. Escudo del cabildo de la catedral de Córdoba en la puerta de Santa Catalina, ca. 1565.

LABORATORIO DE ARTE 28 (2016), pp. 15-40, ISSN 1130-5762 e-ISSN 2253-8305 - DOI http://dx.doi.org/10.12795/LA.2006.i.01.01 


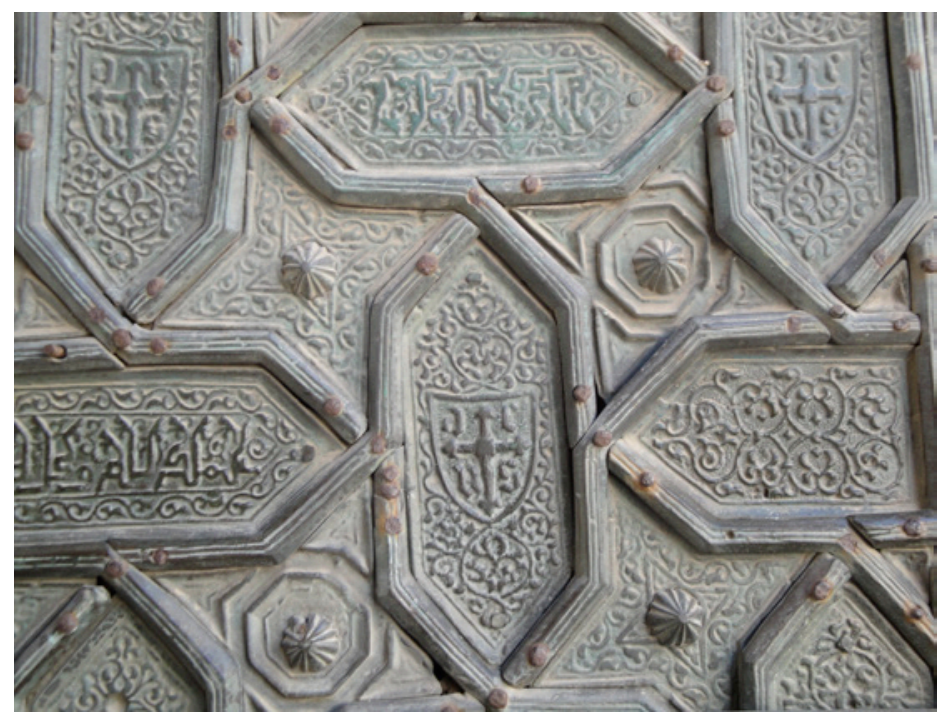

Figura 4. Detalle de la decoración de las hojas de bronce, puerta del Perdón, 1377.

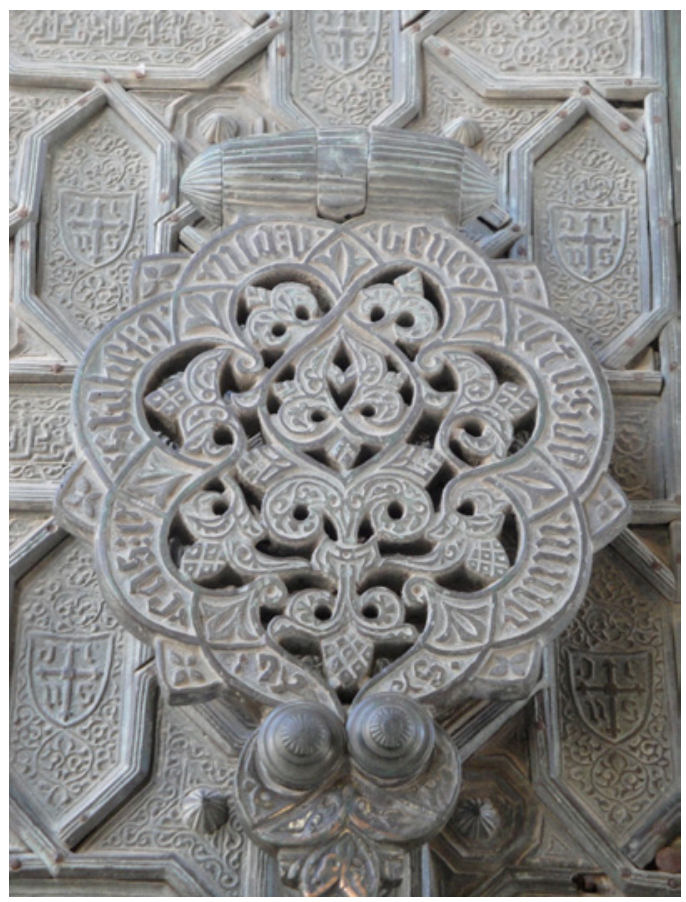

Figura 5. Aldabón de la puerta del Perdón, 1377.

LABORATORIO DE ARTE 28 (2016), pp. 15-40, ISSN 1130-5762

e-ISSN 2253-8305 - DOI http://dx.doi.org/10.12795/LA.2006.i.01.01 


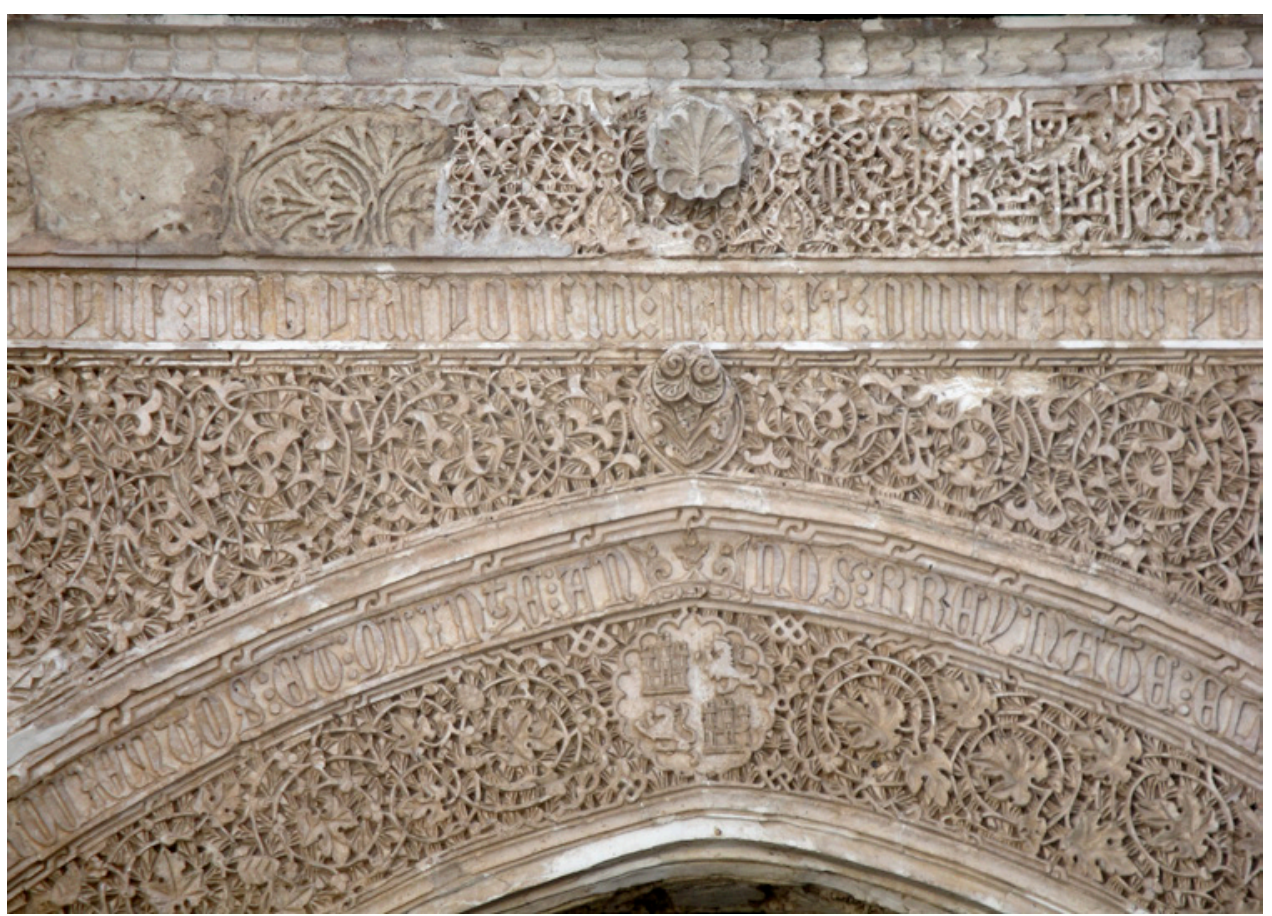

Figura 6. Detalle del alfiz, 1377.

LABORATORIO DE ARTE 28 (2016), pp. 15-40, ISSN 1130-5762 e-ISSN 2253-8305 - DOI http://dx.doi.org/10.12795/LA.2006.i.01.01 


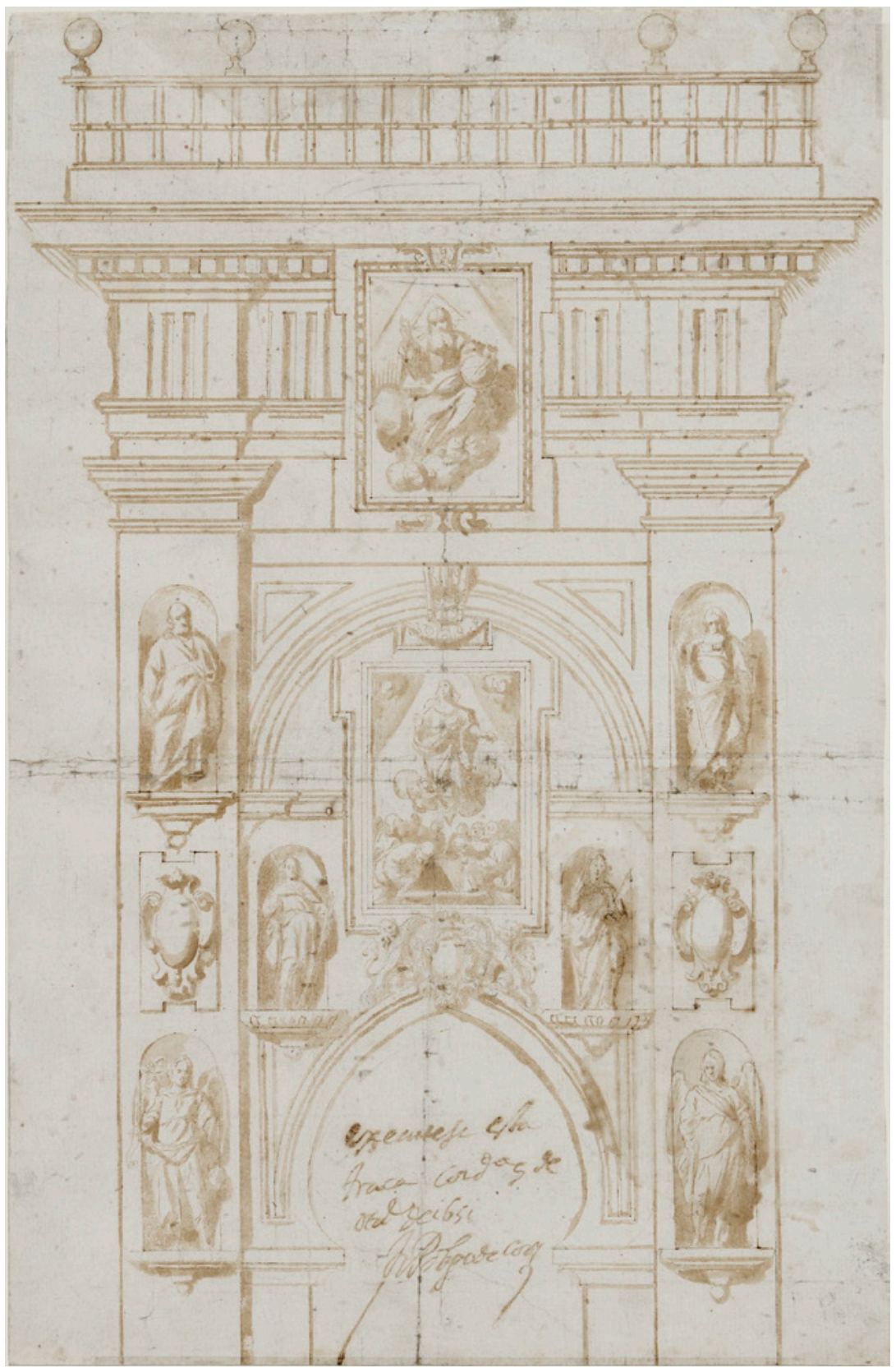

Figura 7. Proyecto para la puerta del Perdón, Antonio del Castillo, 1651, episcopado de fray Pedro de Tapia, Museo de Bellas Artes de Córdoba. 


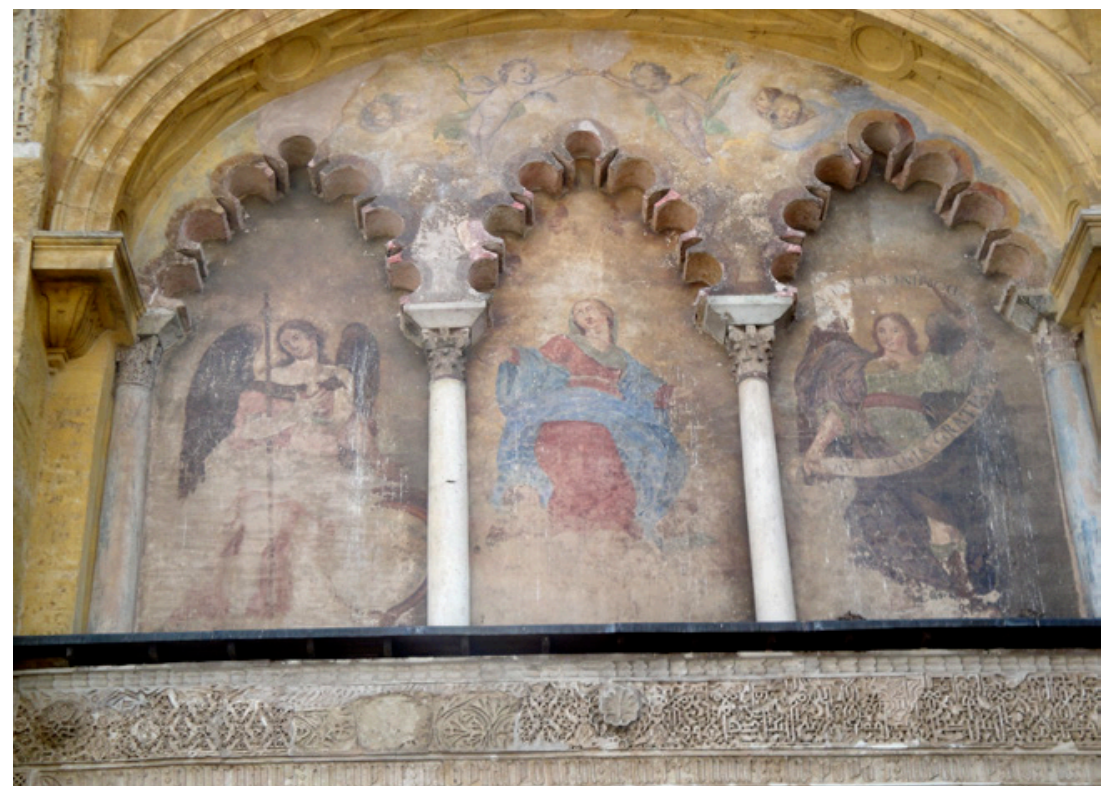

Figura 8. Pinturas atribuidas a Antonio del Castillo, 1651-1652.

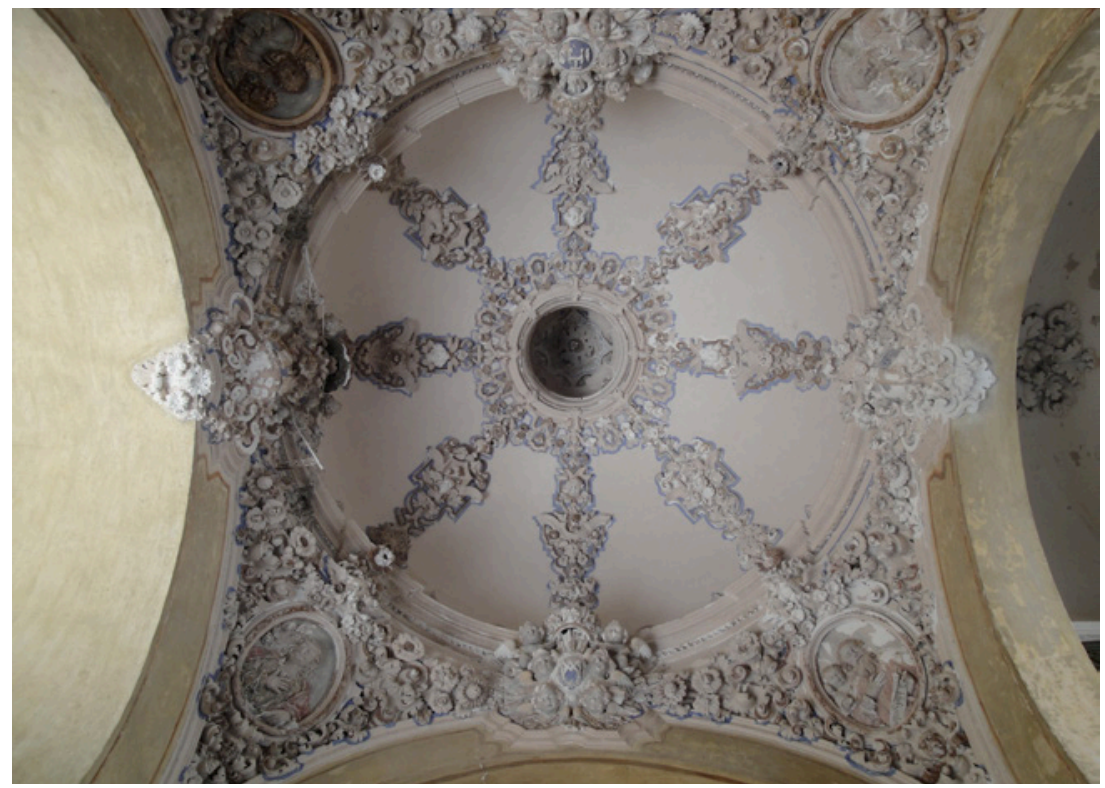

Figura 9. Cúpula de la puerta del Perdón, 1740, episcopado de don Pedro Salazar y Góngora.

LABORATORIO DE ARTE 28 (2016), pp. 15-40, ISSN 1130-5762 e-ISSN 2253-8305 - DOI http://dx.doi.org/10.12795/LA.2006.i.01.01 


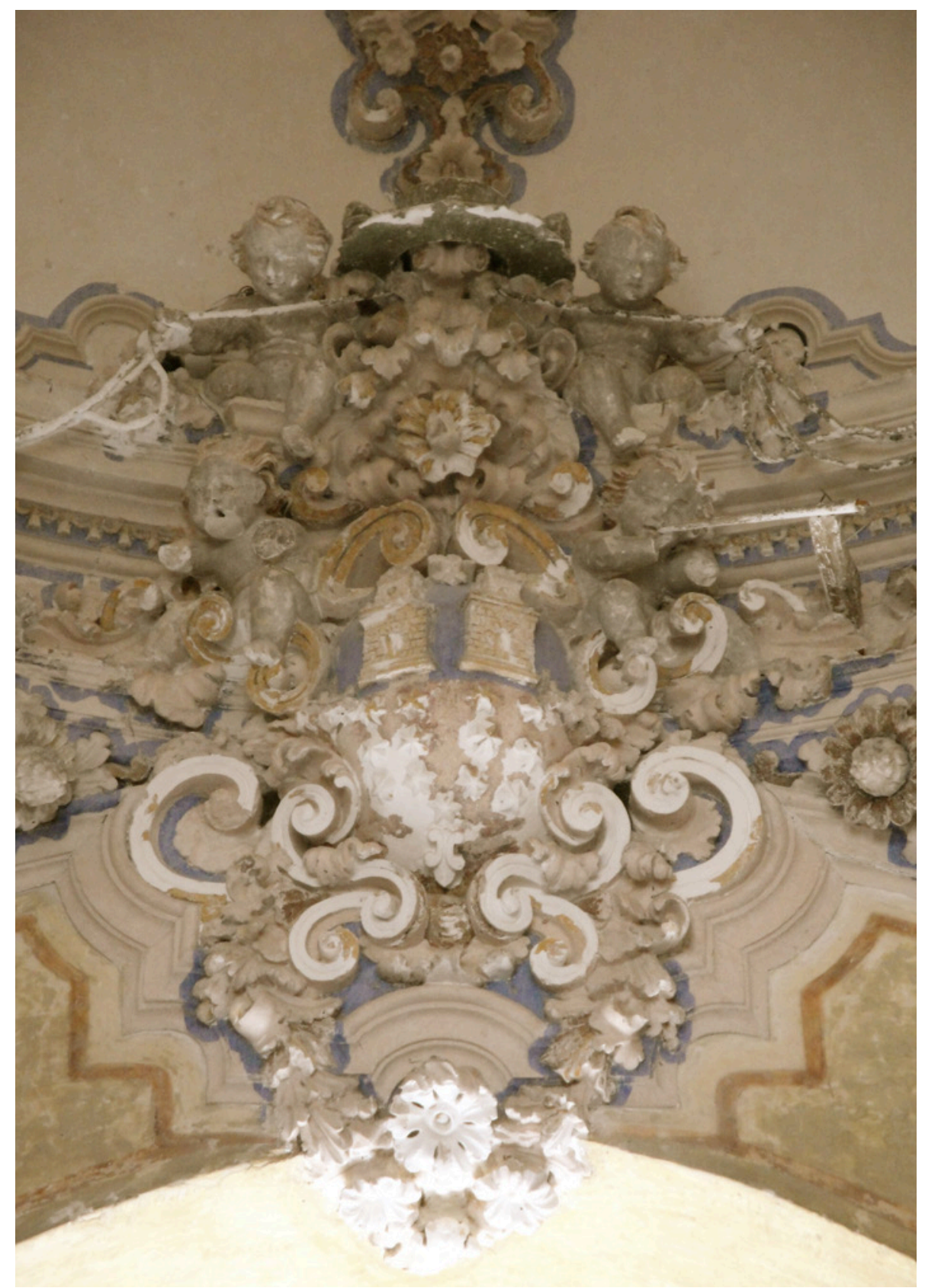

Figura 10. Escudo del obispo don Pedro Salazar y Góngora, 1740.

LABORATORIO DE ARTE 28 (2016), pp. 15-40, ISSN 1130-5762

e-ISSN 2253-8305 - DOI http://dx.doi.org/10.12795/LA.2006.i.01.01 